\title{
Kajian Moral Naskah Babad Dermayu Melalui Pendekatan Hermeneutik dan Implementasinya Sebagai Bahan Ajar Cerpen Berbasis Kearifan Lokal di Kelas XI SMA
}

\author{
Krisnalianita $^{1}$, Emah Khuzaemah ${ }^{2}$, Tato Nuryanto ${ }^{3}$ \\ Institut Agama Islam Negeri (IAIN) Syekh Nurjati Cirebon \\ krisnalianita4@yahoo.co.id, emah.kh69@gmail.com
}

\begin{abstract}
The moral of a literary work is the meaning contained in the story shown to the reader. This research aims to describe the manifestations of moral values contained in the Dermayu Babad manuscript, and describe the implementation of the Dermayu Babad as short story teaching material in class XI SMA The method used in data collection is the narrative analysis method with documentation and questionnaire study techniques and methods used in analyzing data is content analysis with qualitative descriptive techniques. The manifestations of moral values contained in the Dermayu Babad Manuscript are divided into three types, (1) human relationships with God in the form of faith and morals to God, (2) human relations with oneself in the form of honesty, hard working, patience, kindness, courage, respect, and self-confidence, (3) human relations with other human beings in the social sphere are tangible family, friendship and respect for others. The implementation of Dermayu Babad Manuscript as a short story teaching material for high school class XI is done by making teaching materials in the form of textbooks.
\end{abstract}

Keywords: literary works, babad dermayu manuscripts, morals, teaching materials

\begin{abstract}
Abstrak : Moral karya sastra adalah makna yang tekandung dalam cerita yang ditunjukkan untuk pembaca. Penelitian yang ini bertujuan untuk mendeskripsikan wujud nilainilai moral yang terdapat dalam naskah Babad Dermayu, serta mendeskripsikan implementasi nakah Babad Dermayu sebagai bahan ajar cerpen di kelas XI SMA Metode yang digunakan dalam pengumpulan data yaitu metode analisis naratif dengan teknik studi dokumentasi dan angket dan metode yang digunakan dalam menganalisis data adalah analisis konten dengan teknik deskriptif kualitatif. Wujud nilai moral yang terdapat dalam Naskah Babad Dermayu terbagi tiga jenis, (1) hubungan manusia dengan Tuhan yang berwujud keimanan dan akhlak kepada Tuhan, (2) hubungan manusia dengan diri sendiri yang berwujud sifat jujur, bekerja keras, sabar, baik hati, pemberani, rasa hormat, dan percaya diri,(3) hubungan manusia dengan manusia lain dalam lingkup sosial berwujud kekeluargaan, persahabatan dan menghormati orang lain. Implementasi Naskah Babad Dermayu sebagai bahan ajar cerpen untuk kelas XI SMA dilakukan dengan cara membuat bahan ajar yang berbentuk
\end{abstract}

Kata Kunci : karya sastra, naskah babad dermayu, moral, bahan ajar

Sitasi Jurnal:

Krisnalianita, K., Khuzaemah, E., \& Nuryanto, T. (2020). Kajian Moral Naskah Babad Dernayu Melalui Pendekatan Hermeneutik dan Implementasinya Sebagai Bahan Ajar Sastra Berkearifan Lokal di Kelas XI SMA. Disastra: Jurnal Pendidikan Bahasa dan Sastra Indonesia, 2(1), 57-67. doi:http://dx.doi.org/10.29300/disastra.v2i1.1955 


\section{Pendahuluan}

Sejarah adalah hal yang sangat penting dalam kehidupan. Setiap bangsa pasti memiliki histori sejarahnya sendiri. Namun, hanya sebagian masyarakat yang mengerti dan memahami sejarah bangsanya. Pentingnya pemahaman sejarah perlu dimiliki sejak dini agar mampu mengetahui dan memahami makna dari peristiwa masa lampau sehingga digunakan sebagai landasan sikap dalam menghadapi kenyataan hidup di masa depan. Artinya, sejarah perlu dipelajari sejak dini khususnya pelajar sebagai penerus bangsa.

Dalam sejarah banyak terkandung nilai-nilai khususnya moral yang patut dipelajari oleh seorang pelajar, guna menjadi individu yang memiliki etika dan berbudi yang luhur sesuai dengan norma dan hukum yang berlaku. Pada masa sekarang, pelajar cenderung lebih suka mempelajari budaya dan sejarah bangsa lain dibandingkan dengan budaya bangsanya sendiri. Hal tersebut tidak lepas dari arus globalisasi yang semakin kencang mempengaruhi kehidupan serta pemikiran para pelajar. Dampak globalisasi khususnya bagi para pelajar sangat terasa, terbukti dengan banyaknya pelajar yang tidak mengetahui dan memahami sejarah bangsanya sendiri contohnya dalam lingkup yang lebih sempit, yaitu daerah atau kota tempat tinggal asalnya.

Sejarah dan moral sangat erat kaitannya, karena peristiwa-peristiwa dalam sejarah memiliki nilai moral yang patut untuk dicontoh, diteladani dan dilestarikan turun menurun dari generasi ke generasi agar esensi dari sejarah dan nilai-nilai luhur yang terkandung di dalamnya tidak punah termakan zaman. Pelajar sebagai agen of change (agen perubahan) suatu bangsa harus memiliki moral yang baik demi terciptanya bangsa yang sejahtera dan aman. Namun, pada kenyataannya masih banyak pelajar yang belum memiliki moral yang baik. Banyak terjadinya tindakan kriminalitas yang dilakukan oleh pelajar seperti tawuran, penganiayaan terhadap teman, guru bahkan orang tua serta, menjadi pelaku kejahatan seperti pencurian, pengedar narkoba dan lain sebagainya. Kemorosotan moral pada pelajar inilah yang sangat penting untuk segera diatasi.

Permasalahan kemerosotan moral harus memiliki solusi yang baik, salah satu caranya dengan menyisipkan nilai-nilai moral pada pembelajaran di sekolah, contohnya sastra. Dalam karya sastra, moral merupakan suatu hal yang ingin disampaikan oleh pengarang kepada pembaca. Moral merupakan makna yang terkandung dalam sebuah karya sastra. Melalui cerita, sikap, dan tingkah laku para tokoh itulah pembaca dapat mengambil hikmah dari pesan-pesan moral yang disampaikan. Dengan demikian, untuk menanamkan pemahaman sejarah dan meningkatkan kualitas moral pada pelajar, karya sastra khususnya sastra kearifan lokal dapat dijadikan sumber dalam memahami dan meneladani nilai-nilai moral.

Sastra merupakan hasil dari pengolahan bahasa dan budaya yang diciptakan oleh manusia. Menurut Wiyatmi, (2006:9) sastra adalah karya tulis yang jika dibandingkan dengan tulisan lain memiliki berbagai ciri keunggulan seperti keaslian, keartistikan, keindahan dalam isi dan ungkapannya. Karya sastra terbagi menjadi tiga genre, yakni puisi, prosa, dan drama. Dalam terbentuknya sebuah karya sastra tidak terlepas dari unsur-unsur yang membangun karya tersebut.

Babad Dermayu menceritakan mengenai asal usul dari kota Indramayu, yang ditulis dalam bahasa Jawa kuno. Dengan adanya bukti otentik berupa dokumen inilah naskah ini dapat dijadikan karya sastra yang dapat dianalisis. Analisis karya sastra merupakan bagian dari kegiatan apresiasi sastra. Dengan melakukan kegiatan analisis, pembelajaran sastra diharapkan dapat mencapai tujuan apresiatif dan dapat menjadi bahan ajar bagi siswa terutama dalam materi cerpen yang berbasis kearifan 
lokal. Guna mencapai tujuan tersebut sebuah analisis nilai moral sastra untuk naskah Babad Dermayu menggunakan metode analisis melalui pendekatan Hermeneutik.

Pendekatan Hermeneutik adalah suatu teori atau filsafat tentang interpretasi makna. Pendekatan hermeneutik sangat cocok sebagai alat dalam menganalisis naskah Babad Dermayu. Karena dalam pendekatan ini memiliki prinsip-prinsip yang sesuai dengan karakteristik teks naskah yang merupakan karya sastra kearifan lokal yang berisi catatan-catatan sejarah kejadian dimasa lalu. Prinsip tersebut adalah, berkonsentrasi terhadap makna, berpusat pada manusia yakni para tokoh yang diceritakan pada naskah Babad Dermayu, Interpretasi terhadap teks, kontruktsi makna berdasarkan pada intersubjektivitas dalam konteks tempat kejadian fenomena. Sebagai sebuah teks atau wacana, pendidikan menjadi lahan yang subur dalam menerapkan hermeneutika, baik sebagai metode, filsafat, maupun kritik sastra.

Pada Kurikulum 2013 mata pelajaran Bahasa Indonesia, mata ajar sastra tidak terlalu banyak. Posisi tersebut harus diungkap dengan mempertimbangkan mata ajar sastra yang diharapkan dapat mendukung tercapainya tujuan Kurikulum 2013 yang tertuju pada karakter tertentu untuk dimiliki siswa. Kajian karakter menjadi utama dalam kurikulum 2013. Oleh karena itu, materi sastra khususnya cerpen perlu mendapatkan strategi pengembangan materi ajar sastra berdasarkan yang tersedia dalam lingkup Kurikulum 2013.

Cerpen merupakan salah satu mata ajar sastra yang terdapat dalam kurikulum 2013. Materi ini merupakan materi untuk jenjang SMA kelas XI semester ganjil. Penelitian yang dilakukan berkaitan dengan Kompetensi Dasar (KD) yang terdapat dalam kurikulum 2013, yaitu Kompetensi Dasar (KD) 3.8 Mengidentifikasi nilai-nilai kehidupan yang terkandung dalam kumpulan cerita pendek yang dibaca dan
Kompetensi Dasar 4.8 Mendemonstrasikan salah satu nilai kehidupan yang dipelajari dalam cerita pendek.

Badad Dermayu yang merupakan sastra lokal daerah memiliki daya tarik tersendiri baik dari segi historis atau sejarah, bentuk maupun segi isi yang terkandung nilai-nilai khususnya moral di dalamnya sangat baik dipelajari tidak hanya bagi masyarakat yang tinggal dalam satu lingkungan tersebut namun di luar lingkungan tersebut. Menggunakan naskah Babad Dermayu sebagai bahan ajar yang berbasis kearifan lokal yang syarat dengan nilai-nilai luhur tidak hanya sebagai bentuk apresiasi melainkan cara untuk melestarikan budaya yang ada. Hal tersebut sejalan dengan kompetensi inti pada Kurikulum 2013 yang mengedepankan karakter siswa. Hubungan antara kompetensi inti dan kompetensi dasar serta materi ajar yang saling berkesinambungan akan mewujudkan tujuan kurikulum yang diharapkan.

\section{Metode Penelitian}

Metode penelitian merupakan cara ilmiah yang digunakan untuk mendapatkan data dengan tujuan dan kegunaan tertentu. Sudjana \& Ibrahim (2014: 197), mengungkapkan bahwa metode penelitian yaitu prosedur atau cara melakukan verifikasi data untuk memecahkan masalah dalam penelitian. Pendekatan yang dilakukan pada penelitian ini adalah pendekatan kualitatif. Pendekatan kualitatif dalam penelitian ini merupakan suatu prosedur penelitian dengan hasil sajian data deskriptif berupa tuturan para tokoh dalam naskah Babad Dermayu.

Penelitian dilaksanakan pada bulan Februari sampai Mei 2019. Metode pengumpulan data pada penelitian menggunakan metode analisis naratif, dengan dua teknik yaitu teknik studi dokumentasi dan teknik angket. Keabsahan data menggunakan validasi intrarater dan interater. Tahap analisis data menggunakan pendekatan Hermeneutik sebagai pisau 
analisis. Hermeneutik berasal dari kata kerja Yunani hermeneuien, yang memiliki arti menafsirkan, menginterpretasikan atau menerjemahkan.

Validasi bahan ajar menggunakan teknik angket. Menurut Sugiyono (2016: 199) angket adalah salah satu teknik pengumpulan data dengan cara memberikan pertanyaan atau pernyataan secara tertulis kepada responden. Dalam penelitian ini angket digunakan untuk mengetahui kelayakan bahan ajar yang disusun dan dapat dijadikan sebagai bahan evaluasi bahan ajar yang disusun. Dengan demikian, bahan ajar yang disusun dapat dipastikan sebagai bahan ajar yang sesuai dengan persyaratan dan sudah tervalidasi.

\section{Hasil dan Pembahasan}

\section{Nilai-Nilai Moral yang Terkandung dalam Naskah Babad Dermayu}

Naskah Babad Dermayu pada penelitian ini menggunakan naskah koleksi Ahmadi berasal dari Desa Pabean Udik, Kecamatan Indramayu. Naskah ini penulisnya tidak dikenal (anekdot), ditulis menggunakan aksara carakan berbahasa jawa. Bagian naskah pada halaman awal dan akhir tidak ada dan terdapat beberapa bagian yang robek. Babad Dermayu ini di transliterasikan dan diterjemahkan pada tahun 2008 oleh Ruhaliah, yaitu anggota masyarakat pernaskahan nusantara cabang Bandung Jawa Barat, dan bekerjasama dengan Balai Pengelolaan Museum Sri Baduga Dinas Kebudayaan dan Pariwisata Provinsi Jawa Barat yang diberi julukan Babad Dermayu versi 1900. Naskah ini ditulis setebal 124 halaman dengan bahan baku kertas eropa, warna kertas putih kusam karena dimakan usia. Naskah ini memuat cerita asal-usul Indramayu dari awal mula berdirinya hingga masa kolonial Belanda.

Wujud nilai moral pada Naskah Babad Dermayu di klasifikasikan menjadi tiga bentuk yaitu, (1) hubungan manusia dengan Tuhan, (2) hubungan manusia dengan diri sendiri, (3) hubungan manusia dengan manusia lain. Hubungan manusia dengan diri sendiri menunjukan sikap yang melekat pada dirinya. Menurut Samani dan Haryanto (2013) diantara disiplin, jujur, kerja keras, mandiri, rajin, rasa hormat, sabar, dan tanggung jawab.

Hubungan manusia dengan orang lain diwujudkan dengan moral keimanan dan akhlak kepada Tuhan. Wujud nilai moral hubungan manusia dengan orang lain diantaranya adalah ke keluargaan, persahabatan dan menghormati orang lain. Zubaedi (2012: 90-91) menjelaskan bahwa tingkah laku yang berkaitan dengan hubungan manusia dengan manusia lain dapet berupa hubungan seseorang dengan keluarga, masyarakat dan lingkungan masyarakat yang lebih luas.

Tabel 1. Wujud Nilai Moral pada Naskah Babad Dermayu

\begin{tabular}{llc}
\hline No & \multicolumn{1}{c}{ Indikator } & Jumlah \\
\hline 1. & $\begin{array}{l}\text { Hubungan manusia dengan } \\
\text { Tuhan }\end{array}$ & 4 \\
\hline 2. & $\begin{array}{l}\text { Hubungan manusia dengan } \\
\text { diri sendiri. }\end{array}$ & 15 \\
\hline 3. & $\begin{array}{l}\text { Hubungan manusia dengan } \\
\text { manusia lain }\end{array}$ & 9 \\
\hline & Total & 29 \\
\hline
\end{tabular}

Contoh nilai moral hubungan manusia dengan manusia lain terdapat dalam kutipan sebagai berikut.

Sun pasrah(a)ken yang hagung,

Saking karasan[n]e kaki, putra ningsung hayuu..cw, rianangkul dipun tang[ng]is[s]i,

Putra ngambung suku ram[m]a, miwah nang[n]i hingan[n]neki.

Saya serahkan kepada Yang Agung, karena sudah kehendakNya. Anakku, kemarilah. Dipeluk sambil menangis. Putanya mencium kaki ayahnya, kemudian bangkit dan pergi. 
Ungkapan di atas merupakan ungkapan yang diucapkan ibu dari Wiralodra. pada saat Wiralodra meminta izin kepada orang tuanya setelah dalam tapanya menerima wahyu bahwa, jika hidupnya ingin mulia dan keturunannya mendapat kesejahteraan hidup Wiralodra harus membabad (membersihkan) hutan disisi sungai Cimanuk yang mengharuskan dirinya untuk meninggalkan Bagelan. Dalam kalimat ini mengungkapkan kepasrahan dari orang tua Wiralodra atas kehendak Tuhan yang ditunjukan dengan kata "Sun pasrah(a)ken". Ibunya memeluk dan menangis sebagai tanda kasih sayangnya kepada Wiralodra.

Hubungan manusia dengan mahluk lain tercermin pada hubungan seorang anak dengan orang tuanya yaitu Wiralodra dengan ibunya yang sangat dekat saling menyayangi dan mengasihi. Ibunya memiliki cinta kasih kepada anaknya yang sangat kuat tetap menghawatirkan dan menangisi meskipun Wiralodra sudah beranjak dewasa ketika akan pergi mengembara. Begitupun Wiralodra wujud bakti seorang anak kepada bapaknya ditunjukkan dengan sikap mencium kaki ayahnya. Hal tersebut memperlihatkan rasa hormat dan bakti seorang anak kepada orang tuanya.

Contoh hubungan manusia dengan dirinya sendiri terdapat dalam kutipan dialog berikut.

Hugi Radén
sanget nuwun,
bekti habdi nun
katampi,
sangking
sembran[n]a
ka[h]ul[l]a,
prawantu
pawéstri habdi,
kaliyan miskin
ka[h]ul[l]a,
handérék tumut
basuk[k]i.

"Raden saya memohon semoga diterima bakti saya, dari kecerobohan saya, apalagi saya hanya seorang perempuan yang miskin, hanya ingin selamat".

Ungkapan Endang Dharma memohon maaf kepada Wiralodra karena sudah menumpang hidup dan kecerbohannya membuat kekacauan berperang dengan para pangeran Palembang. Ungkapan maaf dan mengakui kecerobohannnya mencerminkan moral jujur, kerena dia mengakui untuk membela dirinya mengakibatkan banyak korban terbunuh dan membuat kerusuhan di desa. Endang Darma mengakui dengan rendah hati bahwa dirinya hanyalah seorang wanita miskin yang hanya ingin mendapatkan keselamatan. Rasa tanggung jawab termasuk ke dalam nilai moral hubungan manusia dengan dirinya sendiri.

Contoh lainnya terdapat dalam dialog berikut.

\section{Nyi Hindang}

nulya humatur,

Duh Radén
humatur habdi,
sumpah hing
hayahan
Tuwan, datan
wantun
hang[ng]langk
ung[ng]i,

hutawi

ngirang[ng]i

kul[l]a,

\section{matur héstu}

kang sayekti,

"Duh Raden saya (akan) mengisahkan, bersumpah di hadapan Paduka, tidak berani melebih-lebihkan, atau mengurangi, (akan) diceritakan yang sesungguhnya."

Ungkapan Endang Darma bahwa
akan menceritakan kejadian yang
sebenarnya dan bersumpah tidak akan


melebih-lebihkan atau mengurangi kenyataan yang terjadi sesungguhnya. Hal tersebut mencerminkan sifat jujur. Kejujuran dalam menceritakan kronologis kejadian yang sudah terjadi agar dapat diketahui. Orang yang jujur merupakan orang yang memiliki integritas. Integritas adalah suatu sifat utuh yang dimiliki oleh seseorang, dalam artian kepribadiannya tidak berkotak-kotak melainkan bahwa ia bersikap dan bertindak sebagai dirinya sendiri. Kesimpulannya adalah pola hubungan manusia dengan dirinya sendiri sudah ditunjukan. Orang yang jujur adalah orang yang memiliki kekuatan hati berjalan pada aturan dan prisnsip hidup yang benar. Zuriah (2015: 45) menuturkan bahwa keutamaan kejujuran orang tersebut tidak akan berbohong atau menipu sekalipun orang tersebut tidak memiliki budi. Hal tersebut tercermin pada kejujuran Endang Darma yang mengatakan bahwa tidak akan berbohong dan bersumpah untuk mengatakan hal yang terjadi sebenarbenarnya.

Contoh hubungan manusia dengan manusia lain terdapat pada dialog berikut.
Sanget
kapéngin
pinanggya,
kalih rama
hibu mami,
manah
paman dén
kariya,
teng[g]ah[h]
ing kén[n]é
dingin, bok
hana tiyang
kang yuda,
trimanen
kongkon
malebhu,
haja dén
télaksaman.

"(saya) sangat ingin bertemu dengan ayah ibuku paman akan ditinggalkan, tinggal di sini dulu, bila ada yang pulang berperang, terimalah (dan) suruh masuk, jangan ditolak".

Wiralodra berbicara kepada $\mathrm{Ki}$ Tinggil bahwa, ia ingin pulang ke Bagelen untuk bertemu ibu dan ayahnya, serta mengetahui bagaimana keadaan Negara/kerajaannya tersebut setelah di tinggal bertahun-tahun lamanya. Moral yang ditunjukan adalah kekeluargaan. Melihat diksi yang diucapkan Wiralodra ketika menyatak kerinduan kepada orang tuanya sudah jelas menunjukkan wujud nilai kekeluargaan. Sejauh apapun Wiralodra mengembara dan mendapatkan kesejahteraan ditempat yang baru namun, masih ingat terhadap orang tua dan negaranya yaitu Bagelen.

\section{Nilai-Nilai Moral yang Terkandung dalam Naskah Babad Dermayu Sebagai Implementasinya Sebagai Bahan Ajar Sastra Berkearifan Lokal di Kelas XI SMA.}

Keberhasilan pembelajaran sangat bergantung kepada desain atau rancangan pembelajaran yang dikembangkan oleh guru. Pengembangan bahan ajar sangat diperlukan untuk menggugah minat siswa dalam belajar. Pengemasan bahan ajar yang menarik membuat siswa lebih senang dan menikmati proses pembelajaran di sekolah.

Dalam pembelajaran tidak hanya aspek pengetahuan yang diterapkan melainkan karakter juga harus ditanamkan oleh guru. Dalam upaya bimbingan karakter tersebut dapat mengambil nilai-nilai kearifan lokal yang sangat baik untuk digali dan di kemas menjadi sebuah bahan ajar. Aspek pengetahuan dan penerapan nilainilai karakter dapat terpenuhi tanpa menggubah materi melainkan mengkolaborasikan materi dengan contoh cerpen kearifan lokal.

Penggalian nilai-nilai budaya lokal menjadi hal yang penting untuk 
mengenalkan budaya bangsa kepada generasi muda sebagai identitas dan jati diri bangsa Indonesia. Budaya lokal yang sarat memiliki nilai-nilai luhur apabila tidak dikenalkan kepada generasi muda dikhawatirkan akan punah. Menurut Hoffman (Khuzaemah, 2018: 3) menegaskan bahwa pemindahan norma kepada generasi penerus hendaknya dilakukan dalam rangka membina moral generasi muda. Dengan transmisi tersebut generasi muda akan memahami nilai-nilai budaya dan norma kehidupan yang dianut dalam lingkungannya.

Naskah Babad Dermayu mengandung nilai-nilai moral kearifan lokal khususnya daerah Indramayu dan Cirebon. Banyak yang tidak mengetahui mengenai naskah Babad Dermayu karena yang lebih terkenal dimasyarakat adalah Babad Cirebon. Padahal, Babad Dermayu dan Babad Cirebon berbeda. Maka dari itu, peneliti memilih naskah Babad Dermayu yang kemudian dikemas menjadi bahan ajar berbentuk buku teks agar dapat diketahui masyarakat luas dan menjadi salah satu upaya dalam membimbing karakter generasi muda khususnya pelajar.

Setelah penulis melakukan analisis nilai-nilai moral yang terkandung dalam Naskah Babad Dermayu dengan menggunakan metode hermeneutik. Langkah selanjutnya adalah membuat bahan ajar terkait dengan materi cerpen, yang dimana materi cerpen ada di kelas XI SMA. Majid, (2013: 173) mengungkapkan bahwa bentuk bahan ajar dapat dikelompokkan menjadi empat, yaitu bahan cetak, bahan ajar dengar (audio), bahan ajar pandang dengar (audio visual), dan bahan ajar interaktif.

Bahan ajar yang akan dibuat oleh penulis menurut karakteristiknya adalah berbasis teks. Implementasi analisis nilai moral pada naskah Babad Dermayu penulis membuat bahan ajar cetak yang berbentuk buku teks. Buku teks ini mengkolaborasikan materi cerpen dengan hasil analisis.
Sehingga, cerita yang tercantum di dalamnya menggunakan cerita Babad Dermayu. Nilai-nilai yang hasil analisis tersebut dijadikan tema bagi siswa dalam menulis cerita pendek.

Pada Kurikulum 2013 Revisi terdapat Kompetensi Inti (KI) dan Kompetensi Dasar (KD) yang harus dicapai oleh peserta didik dalam pembelajaran. Materi cerpen terdapat pada kelas XI SMA semester ganjil. Pada penelitian ini mengacu pada dua Kompetensi Dasar (KD) empat Kompetensi Inti (KI). Adapun KI dan KD materi cerpen yaitu; KI 1 (Sikap Spiritual) Menghayati dan mengamalkan ajaran agama yang dianutnya. KI 2 (Sikap Sosial) Memahami, menerapkan, menganalisis pengetahuan faktual, konseptual, prosedural berdasarkan rasa ingin tahunya tentang ilmu pengetahuan, teknologi, seni, budaya, dan humaniora dengan wawasan kebangsaan, kenegaraan, dan peradaban terkait penyebab fenomena, dan kejadian serta menerapkan pengetahuan pada bidang kajiannya yang spesifik sesuai dengan bakat dan minatnya untuk memecahkan masalah. KI 3 (Pengetahuan) Memahami, menerapkan, menganalisis pengetahuan faktual, konseptual, prosedural berdasarkan rasa ingin tahunya tentang ilmu pengetahuan, teknologi, seni, budaya, dan humaniora dengan wawasan kebangsaan, kenegaraan, dan peradaban terkait penyebab fenomena, dan kejadian serta menerapkan pengetahuan pada bidang kajiannya yang spesifik sesuai dengan bakat dan minatnya untuk memecahkan masalah. KI 4 (Keterampilan) Mengolah, menalar, dan menyaji dalam ranah konkret dan ranah abstrak terkait dengan pengembangan dari yang dipelajarinya di sekolah secara mandiri, dan mampu menggunakan metode sesuai kaidah keilmuan.

Naskah Babad Dermayu adalah sastra kearifan lokal yang ada di daerah Indramayu Jawa Barat. Menilik kepada Kompetensi Inti (KI) yang disebutkan sebelumnya naskah ini memenuhi indikator 
pencapaian pada Kompetensi Inti (KI) tersebut. Sikap spiritual dan sosial dapat ditunjukan dari nilai-nilai moral yang terkandung dalam naskah Babad Dermayu tercermin watak para tokohnya. Wiralodra yang memiliki spiritual yang tinggi, sehingga dapat memberikan contoh dalam hal keimanan. Ahlak atau tingkah laku yang tercermin dari para tokohnya ketika menghadapi permasalahan hidup dapat dijadikan suritauladan dalam bertingkah laku khusunya untuk pelajar.

Pada Kompetensi Inti (KI) ke 3 naskah Babad Dermayu sebagai naskah kearifan lokal, mampu memberikan pengetahuan konseptual, budaya, humaniora dan wawasan kebangsaan. Naskah Babad Dermayu dapat disebutkan menjadi fenomena peradaban, yakni asal usul daerah Indramayu. Sehingga diharapkan dapat menanamkan rasa kebangsaan atau cinta tanah air kepada pelajar. Kompetensi Inti (KI) ke 4 terfokus pada keterampilan. Naskah Babad Dermayu dapat dijadikan acuan untuk mendemonstrasikan dengan melatih kemampuan berbicara siswa untuk mempresentasikan nilai-nilai kehidupan sebuah teks cerpen.

Selama ini bahan ajar yang digunakan di sekolah adalah buku paket. Dalam buku paket tersebut khususnya materi cerpen terdapat contoh cerpen yang terbatas pada beberapa cerpen saja, sehingga membuat siswa bosan. Contohnya seperti cerpen berjudul "Robohnya Surau Kami karya A.A Navis" yang sudah sangat terkenal disemua kalangan, sehingga dirasa tidak menarik lagi. Dengan menjadikan cerita Babad Dermayu sebagai contoh, merupakan suatu inovasi baru dan diharapkan lebih kuat dalam menggugah perhatian serta pengetahuan siswa atau pelajar terutama dalam meneladani nilainilai luhur bangsa sendiri yang patut untuk dilestarikan.

Cerpen terdapat dalam KD 3.8 Mengidentifikasi nilai-nilai kehidupan yang terkandung dalam kumpulan cerita pendek yang dibaca. KD 4.8 Mendemontrasikan salah satu nilai kehidupan yang pelajari dalam cerita. Dalam pembelajaran di KD 3.8 nilai-nilai kehidupan yang terkandung di dalam cerpen akan mengadopsi atau memasukkan nilai-nilai yang terkandung dalam naskah Babad Dermayu. Penulis akan merubah contoh dari cerpen yang biasa digunakan khususnya yang ada di dalam buku ajar yang ada disekolah dengan kutipan-kutipan naskah Babad Dermayu. Naskah Babad Dermayu tidak berbentuk narasi, sehingga akan sulit difahami oleh siswa, maka penulis akan mengemas menjadi narasi cerpen yang utuh namun tidak akan mengubah alur cerita ataupun tokohnya, sehingga mudah untuk diterima oleh siswa.

Buku ajar yang akan ditulis oleh penulis akan dibuat berdasarkan kerangka yang mengacu pada pendapat Kurniasih \& Sani, (2017: 71-73) yakni sebagai berikut.

1) Bagian awal

Bagian awal merupakan bagian yang paling pertama dilihat terdiri dari cover, halaman judul, kompetensi inti dan daftar isi dan daftar tabel, bagan dan gambar. Cover dibuat semenarik mungkin untuk menarik perhatian siswa, caranya dengan menambahkan gambar yang berwarna dan penyajian tulisan yang menarik. Halaman judul, daftar isi dan daftar table, bagan atau gambar dibuat sesuai dengan urutan kerangka buku teks agar buku teks sistematis dan mudah difahami.

2) Bagian isi

Bagian isi merupakan bagian inti dari buku teks. Penyajian buku teks ini sesuai dengan kompetensi dasar yang ada pada kurikulum. Kerangkanya adalah sebagai berikut.

\section{Kompetensi dasar}

Kompetensi dasar adalah kemampuan untuk mencapai kompetensi inti yang harus diperoleh peserta didik melalui proses pembelajaran. Kompetensi Dasat (KD) dalam buku teks yang dibuat adalah 3.8 mengidentifikasi nilai-nilai kehidupan 
dalam kumpulan cerita pendek dan 4.8 mendemonstrasikan salah satu nilai-nilai kehidupan dalam cerita pendek.

\section{Indikator}

Indikator adalah perilaku yang dapat diukur dan diobservasi untuk menujukkan ketercapaian kompetensi tertentu yang menjadi acuan penilaian mata pelajaran yang mencakup nilai pengetahuan, sikap dan keterampilan. Pada buku teks yang dibuat indicator pencapaian adalah mampu menentukan nilai-nilai kehidupan dalam cerpen dan mampu mendemonstrasikan nilai-nilai kehidupan dalam cerpen.

\section{Tujuan Pembelajaran}

Tujuan pembelajaran indikator keberhasilan guru dalam melaksanakan proses pembelajaran.

\section{Pendahuluan}

Pendahuluan berfungsi untuk memantik pengetahuan siswa mengenai nilai-nilai kehidupan yang terkandung dalam cerpen.

\section{Membangun konteks}

Membangun konteks siswa bertujuan untuk menggali pengetahuan siswa sebelum dilakukannya pengajaran atau pemberian materi agar tidak timbul kesalahfahaman dalam memahami konsep materi.

\section{Kegiatan I}

Menemukan nilai-nilai kehidupan pada cerpen berkearifan lokal Penulis menyajikan cuplikan-cuplikan cerpen yang mengisahkan cerita Babad Dermayu.

Tugas kelompok

Penugasan dilakukan untuk menemukan nilai-nilai kehidupan yang terkandung dalam cerpen secara berkelompok. Dalam menemukan nilai-nilai tersebut lebih efektif dilakukan secara berkelompok selain waktunya lebih cepat pemahaman siswa dengan cara berdiskusi satu sama lain, sehingga adanya kebebasan berpendapat dan membuat siswa lebih aktif.

\section{Tugas mandiri}

Tugas mandiri diberikan untuk menambah pemahaman serta wawasan siswa secara mandiri.

\section{Kegiatan II}

Mendemonstrasikan nilai-nilai kehidupan dalam cerpen berkearifan lokal.

Tugas Kelompok

Mendemonstrasikan nilai-nilai kehidupan dalam cerpen berkearifan lokal. Mendemonstrasikan merupakan kegiatan mengenalkan kepada khalayak yang sifatnya persuasif atau mengajak. Setelah siswa mampu menemukan nilai-nilai yang ada pada sebuah cerpen, kegiatan selanjutnya adalah mempresentasikan nilai-nilai tersebut di depan kelas. Nilai-nilai yang dipresentasikan yang dikemas dengan pengetahuan masing-masing melalui cerita atau definisi dapat memberikan pemahaman kepada orang lain dan secara tidak langsung mengajak audience untuk berbuat sesuai dengan nilai yang dipresentasikannya.

\section{Uji kompetensi}

Uji kompetensi dilakukan untuk proses evaluasi mengenai pemahaman siswa terhadap materi.

Tugas mandiri

Validasi bahan ajar berguna untuk mengetahui kelayakan materi ajar. Uji validasi dilakukan oleh dosen pembimbing yang sudah dapat dipastikan memiliki kemampuan dalam menilai kelayakan bahan ajar. Tujuan validasi bahan ajar adalah untuk mengetahui hal-hal yang perlu diperbaiki dalam bahan ajar yang sudah dibuat berdasarkan hasil analisis nilai-nilai moral yang terkandung dalam naskah Babad Dermayu.

Adapun langkah-langkah yang dilakukan dalam proses validasi buku teks adalah sebagai berikut.

a. Menghitung skor rata-rata dari angket menggunakan rumus.

$$
\overline{\bar{X}}=\frac{\sum \mathrm{x}}{\mathrm{n}}
$$


Keterangan:

$$
\begin{array}{ll}
\bar{X} & =\text { skor rata-rata } \\
\sum \mathrm{x} & =\text { jumlah skor } \\
\mathrm{n} & =\text { jumlah subjek } \\
\text { penilaian } &
\end{array}
$$

b. Skor yang diperoleh kemudian diubah dalam bentuk persentase (\%). Menentukan (\%) menggunakan rumus sebagai berikut.

Persentase rata-rata $=$

$$
\frac{\text { Tse }}{\text { TSh }} \times 100 \%=\ldots \%
$$

Keterangan:

TSe $=$ total skor empirik (hasil yang diperoleh dari lembar validasi)

$\mathrm{TSh}=$ total skor maksimal (nilai total yang diperoleh dari lembar validasi)

Dari hasil analisis yang telah dilakukan, menentukan bahan ajar (subbab) unsur pembangun lirik lagu valid atau tidak untuk digunakan. Persentase validitas bahan ajar (subbab) lirik lagu dalam penelitian ini berdasarkan pandangan Akbar (2013: 41).

\section{Simpulan}

Berdasarkan hasil penelitian dan pembahasan ditemukan data-data sebagai berikut. Wujud nilai moral dalam hubungan manusia dengan Tuhannya. Dalam penelitian ini penulis menemukan tiga bentuk varian yaitu kepercayaan terhadap Tuhan, bersyukur kepada Tuhan dan memanjatkan doa. Moral yang paling mendominasi adalah kepercayaan kepada Tuhan atau keimanan.

Wujud nilai moral dalam hubungan manusia dengan diri sendiri Dalam penelitian ini penulis menemukan bentuk nilai moral dalam hubungan manusia dengan diri sendiri dengan berbagai varian yaitu, kejujuran, kerja keras, mandiri, suka menolong, rasa hormat, tanggung jawab, sabar, pemberani, percaya diri dan adil. Sedangkan wujud moral yang paling mendominasi adalah sabar. Wujud nilai moral dalam hubungan manusia dengan manusia lain dalam lingkup sosial. Dalam penelitian penulis menemukan 3 varian, yaitu hubungan kekeluargaan, hubungan seorang raja dengan abdinya dan cinta terhadap tanah air. Wujud nilai moral yang paling menonjol adalah hubungan kekeluargaan terutama antara orang tua dan anak.

Implementasi analisis nilai moral pada naskah Babad Dermayu penulis membuat bahan ajar cetak yang berbentuk buku teks yang mengkolaborasikan materi cerpen dengan hasil analisis.

\section{Daftar Pustaka}

Akbar, Sa'adun. 2013. Instrumen Perangkat Pembelajaran. Bandung: PT Remaja Rosdakarya

Khuzaemah, Emah. 2018. Penerapan NilaiNilai Budaya Lokal Babad Cirebon Untuk Membina Karakter Mahasiswa Melalui Pembelajaran Menulis Kreatif. Dalam http://repositori.kemdikbud.go.id diunduh pada Kamis, 20 Juni 2019 Pukul 18.00 WIB

Kurniasih, Imas dan Berliani Sani. 2014. Panduan Membuat Bahan Ajar Buku Teks Pelajaran Sesuai Dengan Kurikulum 2013. Surabaya : Kata Pena

Majid, Abdul. 2013. Perencanaan Pembelajaran Mengembangkan Standar Kompetensi dan Pemakaian Buku Teks. Yogyakarta: Ar-Ruzz Media

Samani, Muchlis dan Haryanto. 2013. Pendidikan Karakter. Bandung: PT Remaja Rosdakarya

Sudjana, Nana dan Ibrahim. 2014. Penelitian dan Pendidikan. Bandung: Sinar Baru Algensindo. 
Sugiyono. 2016. Metode Penelitian pendidikan: Pendekatan Kuantitatif, Kualitatif. Bandung: Alfabeta.

Wiyatmi, 2006. Pengantar Kajian Sastra. Yogyakarta: Pustaka

Zubaedi. 2012. Desain Pendidikan Karakter: Konsepsi dan Aplikasinya dalam Lembaga Pendidikan. Jakarta: Kencana Prenada Media Group.

Zuriah, N. 2015. Pendidikan dan Moral Budi Pekerti dalam Perspektif Panduan Menggagas Planform Pendidikan Budi Pekerti Secara Konstektual dan Futuristik. Jakarta: PT Bumi Aksara. 